\title{
ANGLO-AMERICAN DRAMA PERFORMED FROM 2005 TO 2015 AT THE NATIONAL THEATRE IN BELGRADE
}

The paper deals with the reception of Anglophone playwrights and types of plays which were performed in the Belgrade National Theatre from 2005/2006 to $2015 / 2016$. It looks at Anglophone theatre from across its borders in the light of Serbian culture and its production conditions. Special attention is paid to the socio-cultural impact it has had on Serbia and its theatre productions. Thus, the paper analyzes the playwrights and their plays which were embraced by the Belgrade National Theatre (Tony Kushner, Tennessee Williams, John Osborne, Mark Ravenhill, Howard Barker, Ronald Harwood), and also tries to uncover why some others were neglected or rejected in this period.

Among other issues, the paper addresses some questions concerning practitioners, program creators and audiences, such as: access to Anglophone theatre, motivation, cultural and repertoire politics, the impact of productions on critics and audiences, etc. Certain questions are discussed through interviews with the practitioners from the National Theatre in Belgrade (Božidar Djurović, former Head of Drama Department of the National Theatre and its General Manager, Radoslav Milenković, theatre director).

Key words: theater, Anglo-American, drama, plays

\section{Introduction}

The National Theater in Belgrade (Narodno pozorište u Beogradu) is one of the most prestigious and oldest theaters in Serbia that was established in 1868 by Prince Mihajlo Obrenović. Since then, the only period when the theater was closed was during World War I when the actors were drafted to fight in the war. The archive of the theater, as well as the theater's collection of plays, made the journey over the Albanian

*_markoradulovic93@gmail.com 
mountains together with the civilians during the Serbian retreat. After the War ended, the theater opened its doors again and to this day, the theater has presented plays by the authors from all around the world like Moliere, Chekhov, Euripides, Moberg, Shakespeare and others to the Serbian audiences. The latest period (2005-2015) is one of the most provocative and asks for a lot of research, which will be presented in this paper. The research will present the perspectives of the practitioners and the critics alike and will start with Božidar Bobo Đurović.

Bobo Đurović, the drama manager for a number of years and the director of the theater between 2009 and 2012, explains how the plays are chosen for the production. He notes:

"I must point out that the drama manager directly influences the choice of the authors to be performed, while the influence of the director of the theatre is indirect - he approves the choice. My choice of plays to be performed on the stage of the National Theatre has always been based on the respectable artworks of high artistic value, whether they come from domestic or world contemporary literature. Apart from the quality, my choices also depend on whether the play's topics would be of interest to our audience at that moment. Of course, there are always some additional reasons which are conditioned by the distribution of roles, technical limitations, genre differences or the very idea of a certain play. The choice is always judged by time.

The National Theatre works under different conditions compared to many other theatres - we have a permanent cast, we are financed by the state, our plays can run long (some have been on the stage for more than 20 years), and there are many other factors" (B.Đurović, personal interview with Radojka Vukčević, July 2, 2018).

To the question about the topics which are of interest to the contemporary Serbian audience, Đurović responded:

"I used to say that drama looks like musical notes: each topic finds its own symbol. Still, some topics can be recognized which impose themselves at this moment: people in power, the 
"white plague," which represents a warning since 7\% more people die in Serbia than they are born, the brain drain, vulnerable groups, sexual orientation (and whether people are open about it or not), ethnic migrations; until recently the hot topic was the war, now it is the corruption in courts, crime, the fear of the Other... I want to point out that the National Theatre has always been open to reacting to the hottest problems in the country and abroad, although it does insist upon a slightly conservative relationship towards the choice of the plays to be performed, their classical reputation and high esthetic values."

Đurovic then explained the position of the Anglo-American drama in relation to this kind of engaged repertoire of the theater:

"Anglo-American drama has never had a special place here. Of course, I must single out Shakespeare, as one cannot imagine the main stage of the National Theatre without his plays. One of the reasons for the weaker reception of other authors is the fact that we share the stage with opera and ballet, which means that we can have only one third of the slots a month, and 10 more slots during the first month after the premiere."

The fact that Anglo-American drama has never had a special place here is the reason why this paper focuses on the plays by Anglo-American authors performed in the National Theater between 2005 and 2015 which try to touch upon the topics and questions relevant to the Serbian audiences, and how well they were received. We will start with the best received author - Shakespeare and his play Hamlet.

\section{Hamlet}

In The National Theater, plays by William Shakespeare are some of the most often performed ones. The research conducted for this paper shows that the Anglo-American playwright with the most plays performed is William Shakespeare. During the period on which the paper is based, there was at least one play by Shakespeare performed each year and the first of them was Hamlet. 
Hamlet premiered on $17^{\text {th }}$ October 2002 on the Main Stage and was a modern take on the classic tale. The play was directed by Ivana Vujić. The general manager of the National Theater at the time, Ljubivoje Tadić, said that the play was part of their "Collected and Selected" season and that Slobodan Beštic was going to be the first Hamlet of the National Theater in the 21 st century ("Sabrano plus odabrano", 2002). During the 2005/2006 season, the first season that this research touches upon, Hamlet was the only play by an Anglo-American playwright that was being performed at the theater.

The play was performed for the last time during the 2008/2009 season. During its lifetime on stage, Hamlet was performed 95 times and was seen in total by 13.048 people (Yearbook of Serbian Theaters, 2010: 46). At the time of its premiere, the play was well received by the audience as the tickets were sold out for the next month as well ("Novo čitanje Hamleta", 2002). But some critics took issue with the play. One such critic was Milutin Mijić who wrote for the newspaper Borba and in his review titled "Hamlet - What was that again?" from $19^{\text {th }}$ October 2002, he was very critical of the play. Mijić was of the opinion the main problem of the play lied in the fact that it was overly "dumbed down". In the review he notes:

"The most radical destruction in this play was wrought upon the text itself. And not because Hamlet recites the famous "To Be or Not to Be" monologue while sitting in the shopping cart but because he does it with no emotion whatsoever. It has been a long time since we have seen a play in which the beauty of the Shakespeare's poetic language, the depth of the dramatic conflicts and the complexity of thought have been so run down" (Mijić, 2002).

In spite of such harsh criticism, the play managed to stay on the theater's repertoire for four seasons. The play's modern Hamlet must have resonated with people, as it had been only few years since Serbia started truly embracing capitalism and democracy. It would seem that the audience saw and accepted the director's vision of the character who, like the audience themselves, has very little in life. 
ANGLO-AMERICAN DRAMA PERFORMED FROM 2005 TO 2015 ...

\section{Romeo and Juliet}

The director Ivana Vujić continued her adaptations of Shakespeare in the 2006/2007 season as well. This time, she brought to life Shakespeare's Romeo and Juliet. The play premiered on $7^{\text {th }}$ November, 2006 on the Raša Plaović stage in Belgrade. The play was performed 14 times in the 2006/2007 season with two guest performances, one in Pancevo and the other in Subotica. In the premiere season, the play was viewed by 3177 people (Yearbook of Serbian Theaters, 2008: 42). This play, too, attracted great interest. Many prominent figures attended the premiere. Celebrities and the members of the Serbian diplomacy alike attended the premiere and enjoyed the familiar tale of love, as it was reported by the daily newspaper Politika on $8^{\text {th }}$ November 2006 (D.D., 2006).

In the 2007/2008 season, Romeo and Juliet was once again performed. This time the play was performed 11 times and was seen by 1803 people (Yearbook of Serbian Theaters 2009: 47). The play was last performed during the 2008/2009 season when it was presented only 4 times and seen by 640 people. We see a downward trend which suggests diminishing interest in Romeo and Juliet and it seems that the play did not really resonate with the audience as every subsequent performance had less attendance than the previous one. All in all, the play finished its run with 29 performances. The total number of viewers thus is 5620 (Yearbook of Serbian Theaters, 2010: 46).

\section{The Merry Wives of Windsor}

Arguably, there was no play in the 2006/2007 season that garnered such attention and was so eagerly anticipated as the adaptation of Shakespeare's comedy The Merry Wives of Windsor, directed by the Czech Oscar winning director Jiri Menzel. In the months leading up to the premiere, numerous newspapers reported on the play and published interviews with the director. In an article from Blic from 29 $9^{\text {th }}$ March 2007 the author said that he directed the play in such a way that it would make both the audience and the actors joyful (Nježić, 2007). Večernje novosti has written a lengthy piece about the premiere where they noted:

"The previous night's premiere of Shakespeare's Merry Wives of Windsor on the Main Stage of the National Theater has 
created an unprecedented tempest, not the one by Shakespeare but a true tempest of celebration and elated ovations.

In the imposing, moveable multifunctional wooden circle, which represents an effective scenographic solution by Geroslav Zarić, round and round the actors of this crazy, merry story go, showing that the tales about the cheated husbands are still met as cheerfully with the audiences today as they were in Shakespeare's time" (Mirković, 2007).

In its opening season, the play The Merry Wives of Windsor premiered on $29^{\text {th }}$ March 2007 on the Main Stage and was performed 12 times, attracting 6095 people. The play was performed for 6 more seasons, ending its run in the 2012/2013 season. The number of performances and the number of people attending are shown in the table below.

Table I. The information taken from the Yearbooks of Serbian Theaters from the 2005/2006 issue to the 2015/2016 issue.

\begin{tabular}{|c|c|c|}
\hline Season & Performances & Audience \\
\hline $2006 / 2007$ & 12 & 6095 \\
\hline $2007 / 2008$ & $17+1$ & 9184 \\
\hline $2008 / 2009$ & 7 & 3347 \\
\hline $2009 / 2010$ & 6 & 2815 \\
\hline $2010 / 2011$ & 7 & 3062 \\
\hline $2011 / 2012$ & 7 & 3553 \\
\hline $2012 / 2013$ & 5 & 1434 \\
\hline
\end{tabular}

\section{Henry VI (Part I)}

Shakespeare's pieces are played often at the National Theater and they are well received by the audience as The Merry Wives of Windsor has shown. We will now take a look at Henry VI (Part I) which was directed by Nikita Milojević. The play Henry VI was co-produced by the National Theater, the Laza Kostic Fund and the Globe Theater.

However, according to the critics, the play was not without its issues. Aleksandra Glovacki argued that the text itself is complicated and complex in its scope as the play moves across vast landscapes and large periods of 
time. The play was also modernized with a round table that dominated the stage which, as Glovacki stated, was a callback to the Knights of the Round Table as well as to the European Union with the use of 12 chairs representing 12 stars of the European Union flag. Nikita Milojević with his dramaturge Ivana Dimić did a wonderful job keeping the play focused, according to Glovacki, but the play suffered from different problems. Glovacki noted that many actors played a few different roles and that it could be confusing for the audience to keep track of the characters. Also, the play was fragmented in order to cover most of the time period and some scenes were better than the others. Many questions, especially about the Maid of Orleans, remained. Even though the play had certain issues, Glovacki praised the cast, saying that they represented our national theater well in London where the premiere was held (Glovacki, 2010).

The play premiered on $11^{\text {th }}$ May 2012 in London where it was performed twice in its first year. In Belgrade, the play was performed 6 times in its first year and it stayed on the repertoire for the rest of the time period covered in this research.

Table II. Data taken from the Yearbooks of Serbian Theaters from the $2011 / 2012$ issue to the $2015 / 2016$ issue.

\begin{tabular}{|c|c|c|}
\hline Season & Performances & Audience \\
\hline $2011 / 2012$ & 6 & 3100 \\
\hline $2012 / 2013$ & 16 & 2407 \\
\hline $2013 / 2014$ & 11 & 3073 \\
\hline $2014 / 2015$ & 7 & 1643 \\
\hline $2015 / 2016$ & 8 & 1687 \\
\hline
\end{tabular}

As we can see, during the time period covered in this research, the play was performed 48 times in Belgrade and seen by 11,910 people. The play was also performed in other cities. In the 2012/2013 season, the play was shown in Bojčinska šuma, Mladenovac, Pančevo, Požarevac, Novi Sad, Loznica and once in Podgorica, Montenegro. In the 2013/2014 season the play was performed once in Inđija, once in Arad, Romania and once in Bursa, Turkey. 
The reception of other British authors at the National Theater in this period was not much different. It starts with John Osborn's Look Back in Anger.

\section{Look back in Anger}

John Osborn's Look Back in Anger is a play about a disillusioned, middle class family that ushered a new era and a new generation of playwrights nicknamed "the angry young men." The story was adapted for the Serbian audience by Boris Lijašević. This play premiered in Pančevo on $22^{\text {nd }}$ February 2007. In Belgrade, it was performed on the Raša Plaović stage. This play is actually a co-production by the National Theater and the Cultural center, Pančevo (Centar za kulturu, Pančevo).

The play received high praise from Politika's theater reviewer Ana Tasić who said that:

“Boris Lijašević very successfully presented Osborn's play, especially because the choice of the text was very strange from the start; namely, here we are talking about a play that is closely tied to the context in which it was created, both cultural and social. [...] However, despite this fact, the play Look Back in Anger is interesting and contemporary because of its scenically effective and inspiring analysis of the issues of love, marriage, adultery and friendship" (Tasić, 2007).

Ana Tasić also noted in her review that the director Boris Lijašević made the play more contemporary and more meaningful to the Serbian audience by trimming down the sociopolitical aspect of the play and focusing more on the interpersonal relationships between the characters (Tasić, 2007).

Look back in Anger was performed for only two seasons despite a great initial reception. In its first year, the play was seen by 2458 people and it was performed 14 times in Belgrade, 5 times in Pančevo, 1 time in Vranje, as well as in Čačak. In Montegro, it was performed 2 times, once in Tivat and once in Podgorica. In its second year the play was performed 11 times in Belgrade, once in Vranje, and once in Podgorica (Yearbook of Serbian Theaters, 2008: 43). The number of people who saw the play in its 
second year was 2023. So, in the end, the play was performed twenty-five times and seen by 4481 people (Yearbook of Serbian Theaters, 2009: 47).

\section{Pool (no water)}

Mark Ravenhill's Pool (no water) premiered $22^{\text {nd }}$ February 2009 on the Raša Plaović stage and was directed by Đurđa Tešić who had this to say about the play: "Structure-wise, this piece is a narration and the main theme is vanity, that is, the emptiness of our civilization ("Praznina u 'Bazenu", 2009)." This play is a somewhat unusual choice for the repertoire of the National Theater especially when compared to the other plays we have discussed. This postmodern play surely was a bold choice that, at least during the premiere, paid off. Blic notes that the play was received with a loud ovation and that the actors had to return to the stage three more times as the applause wouldn't stop ("Trostruki 'bis za 'Bazen bez vode"” 2009).

Pool (no water) stayed on the repertoire for three years but it seems like it failed to maintain interest. Both the number of performances and the number of people attending decreased sharply. The experimental nature of the play, it seems, did not sit well with the audience after all. In the end, the play, in total, was performed 20 times and seen by 2624 people.

Table III. Data taken from the Yearbook of Serbian Theaters, from the $2008 / 2009$ issue to the $2010 / 2011$ issue.

\begin{tabular}{|c|c|c|}
\hline Season & Performances & Audience \\
\hline $2008 / 2009$ & 10 & 1508 \\
\hline $2009 / 2010$ & 7 & 911 \\
\hline $2010 / 2011$ & 3 & 205 \\
\hline
\end{tabular}

\section{Civil Servants}

The next play from an Anglophone playwright debuted on the Raša Plaović scene on 4th November 2010. The play Civil Servants comes from the playwright Ronald Harwood and it was adapted for the Serbian theater by the director Đurđa Tešić. Politika's reviewer Ana Tasić was not only critical of the execution of the play but of the material itself. She maintained 
that Tešić did well considering what she had to work with and praised both the scene designer Igor Vasiljev, and Boris Komnenić who was brilliant in his portrayal of Desmond Morton. On the other hand, Tasić did not like the performance of the play's lead Vuk Kostić. She believed that he was not convincing as a strong individual in a fight against the oppressive government due to his lack of depth, complexity and intensity needed to play a character such as Ralph Wigram. She concluded her review by stating that that kind of didactic realism is not an appropriate way to tackle and show the complex state of our world (Tasić 2009). The highest point of the play was, without a doubt, Boris Komnenić's portrayal of Desmond Morton, a role that made him the recipient of the Raša Plaović Award for the best actor of the season ("Raša Plaović Borisu Komneniću", 2010).

Table IV. Data taken from the Yearbook of Serbian Theaters, from the 2010/2011 issue to the 2012/2013 issue.

\begin{tabular}{|c|c|c|}
\hline Season & Performances & Audience \\
\hline $2010 / 2011$ & 17 & 4262 \\
\hline $2011 / 2012$ & 5 & 682 \\
\hline $2012 / 2013$ & 5 & 597 \\
\hline
\end{tabular}

\section{Scenes from an Execution}

On $22^{\text {nd }}$ November 2011, the director Marko Manojlović brought to the Raša Plaović stage the play written by Howard Barker called Scenes from an Execution. Aleksandra Glovacki, writing for the daily newspaper Večernje novosti, like Ana Tasić in her review of the Civil Servants, noted that the main problem of the play was the text itself. She praised the main actress Gordana Đurđević-Dimić and the actor Aleksandar Đurica, while stating that there were no problems with the director either. For her, this was a story we had seen a thousand times and it brought nothing new to the viewer (Glovacki, 2010).

Večernje novosti published an article about the premiere of the play and the reaction of the audience which was quite positive. The article titled "Ovation for the Execution" pointed out that the cast was met with a ten- 
minute applause and that Gordana Đurđević-Dimić received a standing ovation from the audience ("Ovacije 'Egzekuciji",, 2010).

Table V. Data taken from the Yearbook of Serbian Theaters, from the $2010 / 2011$ issue to the $2011 / 2012$ issue.

\begin{tabular}{|c|c|c|}
\hline Season & Performances & Audience \\
\hline $2010 / 2011$ & 12 & 2220 \\
\hline $2011 / 2012$ & 3 & 214 \\
\hline
\end{tabular}

\section{The Importance of Being Earnest}

Some plays constantly resonate with the audience, and such is the case with the play The Importance of Being Earnest written by Oscar Wilde. With a modern approach taken by the director Nikola Zavišić, Wilde's critique of the Victorian era and the conservative society filled with dandies and hypocritical upper class seems as popular as ever.

The play premiered on the Raša Plaović scene on 14th January 2012 and was met with the approval of both the audience and the critics. Zlatko Paković said that the play was a success stating that the play was a "stylistically impeccable Monty Python-like buffoonery in the spirit of the popular Wilde" and praised everyone, from the cast to the scene designer and costume designer (whom he especially admired) (Paković, 2012).

Ana Tasić also praised the play, primarily the way the play was modernized for the contemporary audience. She spoke highly of the acting and the actors who played the characters as if they had just stepped on a fashion runway. They moved and scrambled in a highly stylized fashion in sync with the beat of the popular music that accompanied them. This way, the context of Wilde's play was connected with the critique of our own media-saturated culture. In Tasić's opinion, like Paković's, everyone working on the play did a magnificent job. According to her, there was only one fault with the play - it was a tad too long, clocking just around two hours. There was some padding in the play in the form of a character's display of arrogance but in her opinion, this did not really hurt the play (Tasić, 2012).

Aleksandra Glovacki added her voice to the praises of this play also noting the successful modern take on the material, saying that the 
characters would look right at home on the fashion runways, TV shows and in celebrity magazines. She described the acting as "stylized, Monty Python-like, grotesque." She concluded by saying that this was a great play and a great choice by the team of the National Theater (Glovacki, 2012).

The Importance of Being Earnest stayed on the repertoire from its premiere until the end of the timeframe taken for this research. Thus, it was performed for five years in conclusion with the 2015/2016 season. The biggest surprise here is a really steep drop in 2011/2012 season as the number of both performances and the audience declined sharply.

Table VI. Data taken from the Yearbook of Serbian Theaters, from the $2011 / 2012$ issue to the $2015 / 2016$ issue.

\begin{tabular}{|c|c|c|}
\hline Season & Performances & Audience \\
\hline $2011 / 2012$ & 17 & 4935 \\
\hline $2012 / 2013$ & 20 & 4122 \\
\hline $2013 / 2014$ & 14 & 2837 \\
\hline $2014 / 2015$ & 14 & 2319 \\
\hline $2015 / 2016$ & 11 & 2108 \\
\hline
\end{tabular}

American authors

\section{Homebody/Kabul}

On the 2009/2010 repertoire, the first play written by an American playwright can be found. Homebody/Kabul was a play chosen to introduce Tony Kushner to the audience of the National Theater. Željko Đukić was a director who tackled this play by Kushner, and according to the critic Ana Tasić, the play did not turn out well.

Tasić was most displeased with how the play turned out, calling it "monotonous" and "watered down." She argued that it was "characterized by a shallow, simplified, illustrated realism which makes the play, as a whole, fairly unconvincing." Tasić did praise the first part of the play and the performance of Dušanka Stojanović Glid who played the role of Homebody, but noticed that things went downhill after that. She concluded that it was a shame that the play "did not adequately manage to showcase 
the truly enormous talents of this writer [Kushner], his direct, cynical, uncompromisingly critical musings on the modern world" (Tasić, 2010). The play premiered on $26^{\text {th }}$ October 2009 on the Raša Plaović stage, but it was performed for only 3 years.

Table VII. Data taken from the Yearbook of Serbian Theaters, from the $2009 / 2010$ issue to the $2011 / 2012$ issue.

\begin{tabular}{|c|c|c|}
\hline Season & Performances & Audience \\
\hline $2009 / 2010$ & 18 & 3321 \\
\hline $2010 / 2011$ & 12 & 1599 \\
\hline $2011 / 2012$ & 2 & 172 \\
\hline
\end{tabular}

\section{The Glass Menagerie}

Up until then, there had only been one play by an American playwright performed at the National Theater and that was Tony Kushner's Homebody/Kabul. The second play from across the pond came from the great Tennessee Williams, whose The Glass Menagerie premiered on $16^{\text {th }}$ March 2012 at the National Theater on the Raša Plaović stage. The Glass Menagerie was brought to the Serbian audience by the director Radoslav Milenković.

Unfortunately, the play was not received well by the critics. Ana Tasic and Zlatko Paković criticized the performance of Bojana Stefanović who over-exaggerated Laura's slight handicap and instead of a shy and introverted person, she portrayed Laura as a seriously mentally challenged person. The performance by Olga Odanović who played the role of Amanda was also not very good as she ignored the notes by Williams and played Amanda as a typical "insensitive, egoistic and vulgar" woman. Paković and Tasic also lamented the loss of the metaphorical dream state of the text (Tasić, 2012; Paković, 2012). Still, as is the case with The Importance of Being Ernest, The Glass Menagerie remained on the last repertoire that falls within the timeframe of this study.

Table VIII. Data taken from the Yearbook of Serbian Theaters, from the $2011 / 2012$ issue to the $2015 / 2016$ issue. 
Marko Radulović

\begin{tabular}{|c|c|c|}
\hline Season & Performances & Audience \\
\hline $2011 / 2012$ & 15 & 2448 \\
\hline $2012 / 2013$ & 15 & 1854 \\
\hline $2013 / 2014$ & 9 & 848 \\
\hline $2014 / 2015$ & 7 & 811 \\
\hline $2015 / 2016$ & 6 & 715 \\
\hline
\end{tabular}

A look at the reception of Anglo-American plays during the decade covered in this research has shown that the audiences have responded better to the plays that correspond with their own experiences. That is why we can respect and admire Milenković's vision who, when asked why he had chosen to direct the The Glass Menagerie at the National Theater at this moment, said:

"Apart from many other reasons and qualities of The Glass Menagerie, the way this play echoes the here and now is the main reason for choosing it at this moment. I do not have any illusions that our performance or any other will change either what is going on here or what is going on now. But I have a need to fight for the right of the weak, the right to infirmity. The Wingfield family has already been destroyed. The play starts many years before the first act, and what vibrates the strongest in it is, as a matter of fact, the love of a brother for his sister and his desire to protect that small blaze of one candle in the world which is "lit by thunders" today. The rights to be weak, the rights to infirmity are, in fact, the rights to the deepest humanity" (R. Milenković, personal interview with Ivana Dimic, 2018). 


\section{REFERENCES}

D.D. Politika [Beograd], 8.11. (2006).

Glovacki, A. (17. jun 2012). Istorija i komentar. Večernje Novosti

Glovacki, A. (26. novembar 2010). Staro i novo. Večernje Novosti

M.N.M. (23. novembar 2010). Ovacije Egzekuciji. Večernje novosti

Mijić, M. (19. oktobar 2002). Hamlet- sta li to bese?. Borba

Mirković, M. (3. mart 2007). Večernje novosti

Novo čitanje Hamleta. (17. oktobar 2002). Politika

Nježić, T. (30. januar 2007). Jirži Mencl odmah pridobio sve glumce. Blic.

Dostuptno preko: https://www.blic.rs/kultura/vesti/jirzi-mencl-odmahpridobio-sve-glumce/12mblq4 [15.06.2018].

Paković, Z. (27. mart 2012). Drvena menažerija. Danas

Paković, Z. (18. jun 2012). Krv, znoj, suze i luftbalon. Danas

Paković, Z. (16. januar 2012). Montipajtonovska bufonerija. Danas

Raša Plaović Borisu Komeniniću. (22. novembar 2010). Pravda

Sabrano plus odabrano. (17. oktobar 2002). Blic

Tasić, A. (9. novembar 2010). Briljantni Boris Komnenić. Politika

Tasić, A. (17. mart 2012). Izgubljena značenja. Politika

Tasić, A. (3. januar 2010). Trapavi realizam. Politika

Tasić, A. (16. januar 2012). Važno je biti pozer. Politika

Tasić, A. (10. mart 2007). Zanimljivo i aktuelno. Politika

Trostruki ‘bis' za Bazen bez vode. (23. februar 2009). Blic

V.V.S. (22. februar 2009). Praznina u Bazenu. Vecernje Novosti

Yearbooks of Serbian Theaters 2005/2006 - 2015/2016. Novi Sad: Sterijino pozorje, 2007-2017. 


\title{
Marko Radulović
}

\section{ANGLO-AMERIČKA DRAMA U NARODNOM POZORIŠTU U BEOGRADU IZVOĐENA OD 2005. DO 2015. GODINE}

\begin{abstract}
Sažetak
Ovaj rad se bavi recepcijom anglofonih dramaturga i tipovima predstava koje su izvođene u Naradnom pozorištu u Beogradu od 2005/2006. do 2015/2016. Rad posmatrana anglofono pozorište iz ugla srpske kulture i uslova produkcije. Posebna pažnja je posvećena socio-kulturnim uticajima na Srbiju i produkciju pozorišnih predstava. Prema tome, ovaj rad analizira dramske pisce i predstave koje je Narodno pozorište u Beogradu prihvatilo (Toni Kušner, Tenesi Vilijams, Džon Ozborn, Mark Rejvenhil, Hauard Barker, Ronald Harvud), i takođe pokušava da otkrije zašto su neki pisci zanemareni ili odbijeni u ovom periodu.

Između ostalog, rad se dotiče pitanja koja se tiču samih pozorišnih stručnjaka, kreatora programa i publike, kao što su: pristup anglofonom pozorištu, kulturna i programska politika, uticaj produkcije na kritičare i publiku, itd. Određena pitanja se obrađuju preko intervjua sa samim stručnjacima Narodnog pozorišta u Beogradu (Božidar Đurović, bivši direktor odseka za dramu Narodnog pozorišta i njegov upravnik i Radoslav Milenković, pozorišni reditelj).
\end{abstract}

